\title{
THE IMPACT OF UNANTICIPATED POLITICAL EVENTS ON STOCKS MARKET RETURNS: EMPIRICAL EVIDENCE FROM SAUDI ARABIA
}

\author{
Fodol Mohamed Zakaria ${ }^{1 *}$, Hassanuddeen Bin Abdul Aziz ${ }^{2}$ \\ *Corresponding author: \\ 1Department of Finance, International Islamic University Malaysia, Jalan Gombak 53100, Kuala Lumpur, Malaysia. \\ fodol.zakaria@gmail.com \\ ${ }^{2}$ Department of Finance, International Islamic University Malaysia, Jalan Gombak 53100, Kuala Lumpur, Malaysia. \\ ahassan@iium.edu.my
}

\begin{abstract}
This study aims to identify the effect of unexpected political-events on Saudi stock market returns based on the efficient market hypothesis (EMH) assumptions. The disappearance of the Saudi journalist Jamal Khashoggi in Turkey is the political event has been determined in this study. The data collected from ten companies traded in the Saudi stock market which accounted for more than 62 percent of the total market capitalization. However, this paper applied the Event Study Methodology. The results showed that the Saudi stock market initially reacted to the event and tried to absorb the information received but could not correct itself in most of the window event period. It seems that the market did not get the relevant news quickly or clearly. So, the information that flow among traders was not readily available for the investors at the same level and time. Ultimately, the Saudi stock market is described as a weak-form market (inefficient).
\end{abstract}

Keywords : Unanticipated political events, the stock market, expected returns, abnormal returns, cumulative returns, event study methodology.

\section{INTRODUCTION}

Stock volatility is essential to know the value of the stock and predict its returns. However, Markowitz, (1952) defined volatility as a risk, because it involves some risks that could affect equity returns in the future. When traders engage in different activities within the market, there are fluctuations in stocks prices that they cannot avoid them by anyway.This may be due to positive or negative news in the market. When the prices of the stocks fluctuate due to volatility and went far from the market equilibrium, the return on investment undoubtedly will be affected. Therefore, the ability to predict potential volatility gives value to the decisions related to asset and capital allocation in various investments, thus managing portfolios well to avoid and minimize risks.

Many studies have done to examine the volatility of prices in stock markets in developed and developing countries alike. Studies attempted to focus accurately on the interaction of financial markets with the news received and their ability to deal with them. In the case of Saudi Arabia, studies of market performance assessment and its sensitivity towards different news were truly rare and few (Kalyanaraman, 2014)asset allocation, risk management, etc. We estimate the conditional volatility of Saudi stock market by applying AR (1. As for unexpected political events and news, and their impact on the shares' returns are virtually, up to this moment, non-found. It is, therefore, immense importance to conduct this study to assist investors and decision makers in the proper planning of their investments and managing the risks of volatility in the stock market.

The unanticipated political event was identified as the disappearance of Saudi journalist Jamal Khashoggi, and the study then tried to ascertain the impact of this incident on Tadawul 
"the Saudi stock market" (STM). The methodology used is Event Study Methodology. Top ten large market capitalization companies in the Tadawul distributed in five sectors was chosen. The paper concluded that the STM responded to the event and was highly optimistic but could not correct itself and absorb the effects of the event.

There are abnormal returns observed during the window period. However, the returns have very high volatility and different, resulted in a blurry vision and inability to precisely define the market direction, and thus not determine the interrelation between stock revenues and the unexpected political event. In terms of efficiency, the results showed that the STM has a weak-form efficiency, at least in the study period. This may be since investors do not obtain information equally and at the same time or the news and information that were followed to the market was relatively distorted. Finally, the paper is organized as follows; introduction, literature-review, methodology, findings \& discussion, conclusion, and study limitations, as well as a list of references.

Obviously, major political events have lasting effects on the parameters of any economy, and although financial markets are the most important economic indicators for any economy, it has high sensitivity to all events and information that used to flow in. Consequently, unanticipated political events often have a strong impact on the performance of financial markets, and its impact, therefore, on the returns of the stock gains an immense importance to the investor, the company and the market alike, because it considered as a thermometer to measure the stock performance and market efficiency in dealing with the media content that often brings different information. Accordingly, this research aims to achieve the following objectives:

1. To determine the impact of unanticipated political event (Jamal Khashoggi's missing) on the returns of Saudi selected companies' shares.

2. To determine the Saudi stock market efficiency and its interaction with the daily political events received.

\section{LITERATURE REVIEW}

Since the economic globalization is growing in a broad sense, particularly infinance, the world economies seek to be more integrated and benefit from the opportunities available in any market across the world. Financial markets are the most accessible platforms for cash flow and its movement among different economic arteries. While allowing capital to flow from global markets to a specific local market, and vice versa in the transfer of domestic capital to another market. Consequently, the financial market is highly sensitive to any positive or negative change that is expected to occur.

In order to benefit from the opportunities of global and regional markets, then attract foreign investments, the market must be efficient and ready to absorb any type of news received, such as economic, political, or social news and treat it with all transparency and firmness. Naturally, political eventsused to affect everything in the state,either at the individual, institutional and state levels. Consequently, financial markets due to their excessive sensitivity are often the first body to respond to any political event, especially the negative political events and news. 
Based on the Efficient Market Hypothesis (EMH), the prices completelyreflect all available information about assets. Thus, any variation in equilibrium prices will reflect the flow of accessible information to market members, and price stability and movement around the equilibrium point are really necessary(Delcey et al., 2018). There are equal cases where market regulation is detected, the efficient flow of information driving the need to form a system ensures that participants receive abnormal gains so as not to break the market equilibrium. (Malkiel, 2003)argued that there is no system can be set up to enable abnormal returns under acceptance of the market equilibrium concept that could be translated into expected returns which formed since the availability of information based on the market performance.

In this regard, it is necessary to mention the three market efficiency forms that Fama, (1970) spoke of, namely; a weak form, a semi-strong form, and a strong form. The weak form is trading in the previous direction, and the semi-strong form the trading move in which the circulation of information available to the public and previous trends, while in the strong-form the trading is strong on any kind of information, whether public or private information (Delcey et al., 2018). As a matter of fact, the market efficiency does not only support short-term investment and provide liquidity; it also makes it easier for firms, including SMEs, to get access to financial products, thus reviving the country's economy as well(Nugroho, Rusydiana, \& Tubastuvi, 2018). Hence, the use of statistical evidence through event study methodology assumes that the market affected by news and information and prices cannot quickly adapt to current (new) information. So, it is necessary to identify the abnormal returns that can surround the share price which resulted from huge volatilities that make the prices do not indicate the real value of the share or company.

For decades, researchers have sought to identify factors that may affect stock returns in any stock market, such as social, political, and economics dimensions. Political aspects often result in risks known as political risks that have a maineffect on investment and financing decisions, particularly in the emerging markets and developing economies. Henisz \& Zelner, (2003) defined political risks as a variety of risks associated with working abroad. While Clark, (1997)cited political risks as random elements and additional to the timing of political announcements (events) that might create losses.

There is no doubt that political events have very large negative economic and financial consequences on the economy in general and the stock market particularly. Its effects are felt everywhere (global events) or may be limited to one country or region (local events). The political risks naturally are associated with multiple sources and causes of emergency, but they are often interdependent and difficult to differentiate them (Suleman, 2012).

In Pakistan, Suleman, (2012) conducted an empirical study by using EGARCH that introduced by (ENGLE \& NG, 1993)to measure the impact of political-risk (Uncertainty) on the stock market. The study addressed the impact of political news on stock market returns and volatility. The political news simply divided into good and bad news. The results, therefore, showed that good news has a positive impact on stocks' returns, and therefore, reduced volatility. While the bad news leads to reduced returns and increased volatility. However, the increase in the volatility level in the case of bad news is much higher than the increase in returns caused by good news. Indeed, these results confirm important the role of political events and news and their impacts on economic activities which will affect financial markets. 


\section{MENA Stocks Market \& Volatility}

Chau, Deesomsak, \& Wang, (2014)studied the impact of the civilian revolutions in the Arab region (Arab Spring) and the political intricacies as well as the volatility and combination of the main stock markets in the Middle East and North Africa region (MENA). Different GARCH models were used to estimate the asynchronous dealing, the subject heterogeneous ambience, and asymmetric fluctuations. The study concluded that the Arab Spring has contributed to the volatility of equity markets in the MENA region significantly. However, based on this article there is few or none influence on the integration of these markets with the global business.

The previous findings have a strong connotation of the model's specifications and are therefore consistent with the results of previous studies that political ambiguity presents to business volatility immediately. This indicates that the movement of financial asset prices driven by political events as well as by common financial and economic factors. It should be noted that the study included more than one country in two different continents, which makes the efforts somewhat dispersed, so the results may not be accurate in describing a particular case in a country of study samples unless the results of independent studies in that country or taking some variables of the country.

\section{Saudi Stocks Market \& Volatility}

Since decades ago, there many studies discussed stock market volatility widelyin developed and emerging markets over the world (Baillie \& DeGennaro, 1990). However, the context of the Saudi stock market showed a lack of specialized studies and research, only few studies conducted (Brailsford \& Robert, 1966; Kalu O. Emenike, 2010; Kalyanaraman, 2014; Tse, 1991)asset allocation, risk management, etc. We estimate the conditional volatility of Saudi stock market by applying AR (1, and thus making the outlook relatively difficult.

The Saudi Stock Market is known as Tadawul All Share Index (TASI), and its existence dates back to the 1970s when it emerged informally (Kalyanaraman, 2014)asset allocation, risk management, etc. We estimate the conditional volatility of Saudi stock market by applying AR (1. In 2012, the Saudi Stock Exchange was listed and includes 15 sectors. From 2004 to 2012, the number of listed companies increased from 73 companies officially registered in 2004 to 158 companies in 2012. At the same year, the market value of shares issued was SR1400 billion which represents 52.5 percent of the Kingdom's gross domestic product (GDP).

According to TASI's, (2018) statistical reports, the market value (MV) of the issued stocks at the end of the first nine months of 2018 was SR 1899.53 billion, equivalent to USD 506.54 billion. In October 2018, the market value of all issued shares amounted to 1881.80 billion Saudi riyals, equivalent to 501.81 billion US dollars, recording a decline of 0.93 percent compared to the results of September. At the end of November 2018, the market value of all shares amounted to SR 1822.21 billion equivalent to the US \$ 485.92 billion. Obviously, the MV dropped by 3.17 percent from the previous month. Overall, the performance of the Saudi stock market recorded deterioration and decline in the MV since the beginning of the last quarter of the current year. 
To demonstrate on that results, the current study seeks to identify the impact of the unanticipated political event (Jamal Khashoggi's missing) on the returns of equity in TASI, and how the market responds and absorbs these events and political information by applying event study methodology. The following section illustrates the concept of Event study methodology, and how it is applied to the study sample.

\section{Research Hypotheses}

What distinguishes this study is that there is no study in the literature addressing with such unexpected political events. Thus, the results of the current study will add scientific value in the field of financial market efficiency studies gand provide relevant information for the current era.Hence, the basic hypotheses of the study can be established as follows.

H1: There is a negative relationship between unanticipated political events and stocks'returns of listed companies in Tadawul.

H2: Unanticipated political events have a significant effect on the shares' returns of listed firms in Tadawul.

\section{RESEARCH METHODOLOGY}

In this study, "Event Study Methodology ESM" used to measure the effect of unanticipated political events on Saudi Arabia's abnormal stock returns. The Event Study Methodology is widely used in the stock market as empirical studies to investigate the relationship between stock prices and the occurrence of a given event, and hence its impact on stocks returns.

\section{Study Population}

The study population is listed companies in Tadawul (the Saudi stock market). The total number of companies is around 188 companies according to Tadawul annual report for 2017 (TASI, 2018).

\section{Study Sample and Data Collection}

The study sample was restricted to the 10 largest companies listed on Tadawul the Saudi Stock Market by the size of market capitalization. According to Gulfbase, (2018) the capital of these companies represents almost 62 percent of the total capital in the stock market. Therefore, it is believed that these companies represent the Saudi stock market significantly. If they affected, the market is also will follow them. Because of this, they were chosen as a sample representing the rest of the companies in the Saudi stock market (approximately 187 companies) which their capital represents only 38 percent of the total market capitalization. The companies are:Almarai, Saudi Arabian Mining, Saudi Basic Industries, Saudi Electricity, SABB, Riyad Bank, Samba Financial Group, Al Rajhi Bank, The National Commercial Bank, and Saudi Telecom. The data (daily prices) downloaded from the website www.gulfbase.com, and the period is limited from 19/12/2017 to 19/12/2018. See table 1 . 


\section{Event Study Methodology Framework}

This section includes the presentation of the general concept of event study methodology by addressing its origin, concept and steps.

The study of Dolley, (1933) is the first study that used event study methodology to examine changes in stock prices. The study includes other areas of knowledge to assess the influence of announcements on the company's value, such as management, economics, law, accounting, etc. (Mackinlay, 1997). However, the study ofFama, Fisher, Jensen, Eugene Fama, \& Roll, (1969)is considered as a core study used ESM in the social sciences (Ball, 2014). The ESM has increased in the late 20th century due to the sharpness of economic fluctuations and a large number of changes sweeping financial companies and markets, which makes them resort to constant search for appropriate solutions and identify the seeds of possible change (MacKinlay \& MacKinlay, 1997)

\section{The Concept of Event Study Methodology}

In the first place, the ESM is a statistical method used to evaluate the impact of a given event or sequence of events on the value of stock and bond prices as well as exchange rates. The event study method selects a certain period around the event and measures the differences between the "actual return" of the selected stocks and "expected returns", these differences are called the abnormal returns (AR), which refer to the market reaction toward the trend of that event (Park, 2004).

On other hands, the event study begins with the assumption that said a specific event at a precise time could affect the firm value. The effect, accordingly, appears as abnormal return that a result of shares' price changes. The event study methodology aims to test "the null hypothesis" that considers ARs the average rate of return" should equal to zero during the period of the event. To achieve this, it is necessary to know the AR during the event period, which is the essence of "Event Study Methodology, and it is merely the change between the real shares' returns, during the event period, and the expected return. This difference refers to the reality that share prices reflectthe value of the asset (Ball, 2014).

In brief, methodological steps to apply event study methodology are standard, thus it could be applied in various economics and financial studies (Gul, Khan, Saif, Rehman, \& Roohullah, 2013)natural calamities and terrorism on the share prices of the financial sector of Pakistan. A sample of 14 companies are selected randomly from the financial sector (Insurance and Banking. The following points will illustrate the event study steps.

\section{The Identification of Unanticipated Political Event"}

The political event that to be addressed in this study is the missing of Saudi journalist Jamal Khashoggi who disappeared in Saudi Arabia's consulate in Turkey on October 02, 2018. It could be believed that there is considerable ambiguity about the circumstances of the incident. The Turkish authorities conducted extensive investigations but did not reach the end results until the moment. However, they accused a dozen Saudi men who have high positions in the government. World leaders, financial and media institutions as well as individuals around the world reacted to this issue surprisingly and called on the Saudi authorities to take a firm stand on this issue and bring criminals to justice. 
However, this incident attracted people's emotions widely and resulted in Led to a business boycott of the investment conference "Davos Sahara" as well as the statements of US President Donald Trump vowing severe punishment for Saudi Arabia in the case of proven its involvement as a state in the disappearance of Khashoggi. In addition to the Central Intelligence Agency (CIA) declaration that accused Saudi Crown Prince Mohammed bin Salman. Based on these evidences, it can be assumed that this political event has an impact on stock returns in the Saudi financial market. Especially the speech of US President Donald Trump on October 14, which we strongly believe has an impact on the Saudi stock market. Certainly, the event is not yet over, and its effects may also be ongoing, but through Event study methodology it could be demonstrated the impact at least in the short period.

\section{Event Day}

The identified event is the announcement of U. S president Donald Trump, threatening Saudi Arabia with serious sanctions if proven involvement in the assassination case, which is on October 14, 2018. This event is known as the substantive political event, where the date of the event was quite specific for all study companies.

\section{Determination of Event Window}

Event Window or event period uses to determine a specific period before and after the event, normally the period used is 5 or 10 days (Park, 2004). This study chose 10 days before and after the threat announcement by the US President to be the window of the event because the event is large, and its effects are continuing. So, it is better to give a relatively large period so that the differences and deviations can be better observed. The pre-event period is to test the extent of leakage of information or expectations of investors and their anticipation of possible news. The period post- event is a period that seeks to test the market's ability to absorb the information flowing to it quickly and fully. Accordingly, the total duration of the event used in this study is 41 days. $(t=-10, \ldots, 0, \ldots, 10)$

\section{Test Period Determinant}

The test period generally refers to the period that includes the event day and the Event Window. Therefore, the test period of this study is 21 days.

\section{Estimation Period}

The estimation period is a period preceding the event window and used to estimate market model parameters Alpha and Beta $\left(\alpha_{\mathrm{i}}, \beta_{\mathrm{i}}\right)$. According to Warner \& Brown, (1985) the daily use of stock prices for 120 days is sufficient to estimate the period, thus accurately calculating the event window. However, this study uses 250 trading days to estimate this period andanalyzethe event period. Figure (1) shows the timeline for the event study. 


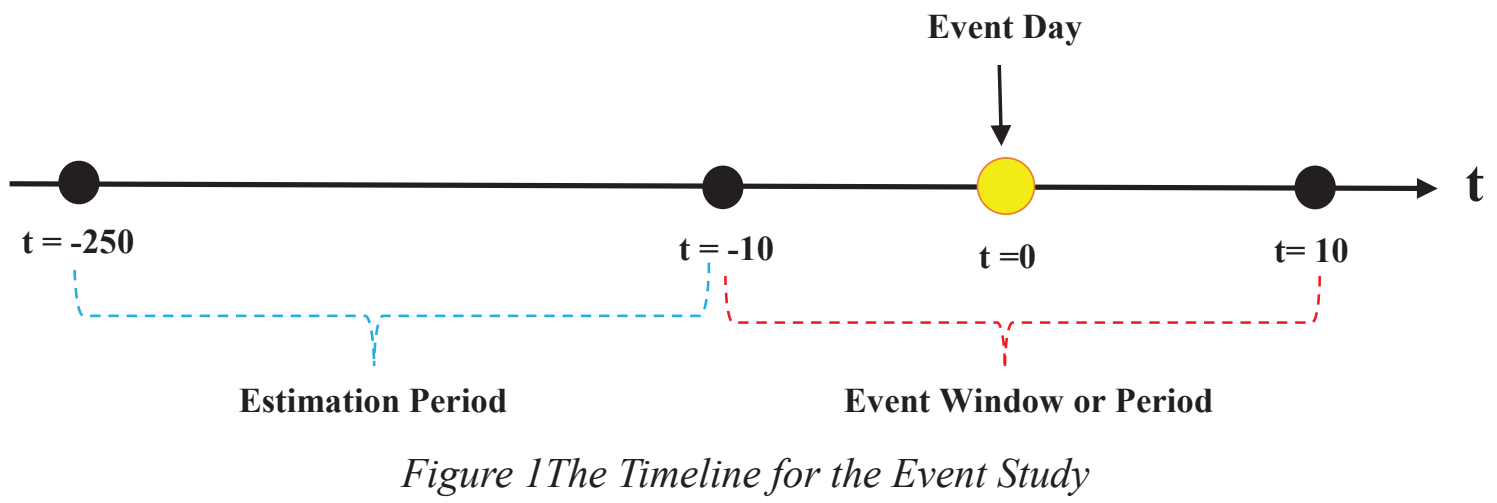

\section{Normal Return Estimation}

The normal returns per share cannot be obtained directly, so it must be estimated through an appropriate approach. The regression analysis was used as a basic approach to measure the normal return on equity based on market performance. This study adopted the Capital Asset Pricing Model (CAPM) because it is a most widely model used for estimating stock returns (Hirschey \& Mark, 1989; Hovav \& D’Arcy, 2003; MacKinlay \& MacKinlay, 1997). Thus, to estimate the stock normal returns, the study used the market modelwhich is the most popular form utilized in the tests. The model is based on a linear relationship between the return on a firm's share and the return on the market index. The model, mathematically, represented as follows:

$$
\boldsymbol{R}_{i t}=\propto_{i}+\boldsymbol{\beta}_{i} \boldsymbol{R}_{m t}+\varepsilon_{i t}
$$

Were;

$\boldsymbol{R}_{\text {it }} \quad$ : The normal excepted return for the share $i$ during period $t$.

$\propto_{\boldsymbol{i}}, \boldsymbol{\beta}_{\boldsymbol{i}}$ : Represent market coefficient for share i in period $\mathrm{t}$

$\boldsymbol{R}_{\boldsymbol{m} \boldsymbol{t}} \quad$ : Market return $\mathrm{m}$ in period $\mathrm{t}$

$\varepsilon_{i t}:$ Random error, and the value of the impact of information in the institution/stock.

There are many studies have applied different approaches to calculating the periodic share's returns. Consequently, there is no consensus on the preference of any method. However, this study adopted the method that mentioned by Park, (2004) to calculate the average return per share.

$$
" R_{\mathrm{it}}=\frac{\mathbf{P}_{\mathrm{it}}-\mathbf{P}_{\mathrm{it}-\mathbf{1}}}{\mathbf{P}_{\mathrm{it}-\mathbf{1}}}
$$

Where;

" $P_{i t}$ : The closing price of the share ${ }_{i}$ on day ${ }_{t}$

$\mathbf{P}_{\mathbf{i t - 1}}$ : The closing price of the share ${ }_{\mathrm{i}}$ before the day ${ }_{\mathrm{t}}$

Similarly, the market return (Rm) on the Saudi stock market (TASI) was calculated on day taccording to the following equation": 


$$
" R_{\mathrm{M}}=\frac{L_{i t}-L_{i t-1}}{L P_{i t-1}}
$$

Were;

$\boldsymbol{L}_{i t} \quad$ : Market closing price of day ${ }_{\mathrm{t}}$.

$\boldsymbol{L}_{i t-1}$ : Market closing price, before day ${ }_{\mathrm{t}}$

\section{Measurement of Abnormal Return $A R_{i t}$ "}

The abnormal return simply is the difference between the normal returns per share during the period of a specific event, and the expected return from the market model. This difference only shows the impact of the company's information on equity prices, i.e., abnormal profits or losses on stock prices, as a result, of a political event or any announcement. The abnormal returns often measured by the following equation:

Were;

$$
\boldsymbol{A} \boldsymbol{R}_{t}=\boldsymbol{R}_{i t}-(\boldsymbol{E}) \boldsymbol{R}_{i t}
$$

$\boldsymbol{R}_{\text {it }} \quad$ : Returns on the stock $i$ in period $t$

$(\boldsymbol{E}) \boldsymbol{R}_{i t}$ : Expected return on share ${ }_{\mathrm{i}}$ in period ${ }_{\mathrm{t}}$

\section{Calculation of Cumulative Average Return CAR}

The Average Cumulative Abnormal Return is calculated for whole event period, to check the market's response to the event, and thus the extent to which political event can be used to achieve an extraordinary return. The CAR is calculated as follows:

$$
C A R_{i t}=\sum_{t=-10}^{t=10} A r_{i t}
$$

Were;

$\boldsymbol{A} \boldsymbol{r}_{i t}$ : Abnormal return average in the day ${ }_{t .}$

\section{FINDINGS \& DISCUSSIONS}

This section will describe the study sample and then discuss and analyze the results presented by the event study methodology in order to provide a clear and integrated vision.

Table 1 Top Market Cap Companies

\begin{tabular}{|l|c|c|c|}
\hline Companies' Names & Symbol & Sector & Cap. (\%) \\
\hline Almarai Co & ALMARAI & Food \& Beverages & 2.58 \\
\hline Saudi Arabian Mining & MAADEN & Materials & 3.06 \\
\hline Saudi Basic Industries Corp. & SABIC & Materials & 19.04 \\
\hline Saudi Electricity Co. & SECO & Utilities & 3.41 \\
\hline SABB & SABB & Bank & 2.69 \\
\hline Riyad Bank & RIBL & Bank & 3.18 \\
\hline Samba Financial Group & SAMBA & Bank & 3.26 \\
\hline Al Rajhi Bank & RJHI & Bank & 7.46 \\
\hline The National Commercial Bank & NCB & Bank & 7.76 \\
\hline Saudi Telecom Co. & STC & Telecommunication Services & 9.88 \\
\hline Other Companies & Others & Other Sectors & $\mathbf{3 7 . 6 8}$ \\
\hline TOTAL & $\mathbf{1 0}$ & $\mathbf{5}$ & $\mathbf{1 0 0}$ \\
\hline
\end{tabular}


Table 1 shows the names and number of names of 10 sample companies from different sectors. Five companies from the banking sector, two from the materials sector, one from the food \& beverage sector, one from the telecommunications sector and the last one is from the utilities sector. As a matter of fact, these companies represent 62 percent of the market cap of all market shares.

Table 2 The Average results of all sample companies

\begin{tabular}{|c|c|c|c|c|c|}
\hline Days & [E] Return & AR & CAR & AR T-test & Sign. \\
\hline-10 & $0.06 \%$ & $-1.14 \%$ & $-1.14 \%$ & -0.7907 & No \\
\hline-9 & $0.10 \%$ & $0.59 \%$ & $-0.55 \%$ & 0.3538 & No \\
\hline-8 & $0.07 \%$ & $-0.54 \%$ & $-1.09 \%$ & -0.3723 & No \\
\hline-7 & $0.08 \%$ & $-0.56 \%$ & $-1.66 \%$ & -0.2643 & No \\
\hline-6 & $0.12 \%$ & $-4.47 \%$ & $-6.13 \%$ & -2.9148 & Yes \\
\hline-5 & $0.06 \%$ & $-2.61 \%$ & $-8.74 \%$ & -1.9837 & Yes \\
\hline-4 & $0.09 \%$ & $3.81 \%$ & $-4.93 \%$ & 2.6100 & Yes \\
\hline-3 & $0.10 \%$ & $2.16 \%$ & $-2.77 \%$ & 1.5654 & No \\
\hline-2 & $0.20 \%$ & $-0.93 \%$ & $-3.70 \%$ & -0.6222 & No \\
\hline-1 & $0.19 \%$ & $-0.28 \%$ & $-3.98 \%$ & -0.1289 & No \\
\hline & & & & & \\
\hline 1 & $0.04 \%$ & $1.24 \%$ & $-2.01 \%$ & 0.7204 & No \\
\hline 2 & $0.08 \%$ & $-3.08 \%$ & $-5.09 \%$ & -1.8943 & Yes \\
\hline 3 & $0.08 \%$ & $-0.83 \%$ & $-5.92 \%$ & -0.4263 & No \\
\hline 4 & $0.07 \%$ & $4.63 \%$ & $-1.29 \%$ & 2.9158 & Yes \\
\hline 5 & $0.08 \%$ & $-1.25 \%$ & $-2.54 \%$ & -0.7612 & No \\
\hline 6 & $0.12 \%$ & $0.10 \%$ & $-2.43 \%$ & 0.1184 & No \\
\hline 7 & $0.09 \%$ & $-0.18 \%$ & $-2.61 \%$ & -0.0909 & No \\
\hline 8 & $-0.05 \%$ & $0.55 \%$ & $-2.06 \%$ & 0.3258 & No \\
\hline 9 & $0.09 \%$ & $-0.71 \%$ & $-2.77 \%$ & -0.4830 & No \\
\hline 10 & $0.06 \%$ & $-0.62 \%$ & $-3.40 \%$ & -0.4089 & No \\
\hline
\end{tabular}

Table 2 shows average expected return E(r), abnormal return (AR), cumulative abnormal return (CAR) and t-value, as well as the statistical significant level of the determined event window of -10 to +10 days. Which is taken into consideration 10 days before and another 10 days after the unanticipated political event day for overall TASI index.

The pre-event period explains the behaviour of the Saudi stock market after Khashoggi's missing. The Saudi stock market started its operations with a two-week gap after the incident, in the absence of clear political news. The statistical values indicate that the market has shown a high degree of response to this event. This response appeared in the different data for each day during the event window. It was clear from the table that the values of t-test on the second and the third day after the event consecutively were significant (-1.8943 \& 2.9158), indicating that the speech of the US President regarding the disappearance of Saudi journalist Jamal Khashoggi had an impact on the Saudi stock market. The negative sign indicates that the market has reacted negatively to this event.

Moreover, statistical values indicate that there are statistical significances that the market affected by this event in the days prior to the speech. From the fourth to the fifth day, 
the t-values were sequentially $(-2.9148,-1.9837, \& 2.6100)$, then after these days, the market started to turn more negative but not significant until the day of the event itself. This may explain that investors are in a state of anxiety and have a blurry vision and may be waiting for substantive news but are unable to predict their exact direction. Hence, risk-averse investors may be taking precautionary steps to avoid any potential risk. This behaviour could give a negative signal to the stock market.

On the other hand, this fuzzy position may the risk-taking investors explain it as an opportunity to make abnormal profits and be very optimistic about any potential political news that may take place on the market, so the market will translate this behaviour into a positive signal. Therefore, the results were negative on the fifth day and positive on the next day by the low values of the t-test parameter.Figure 2 shows the relationship between shares' expected returns that should be realized if this event does not occur and abnormal returns achieved afterward the Event Period. At the beginning of the "event window" (day -9), stock returns began to decline gradually. Even in the day (-6), there was a sharp drop in stock movement and the market losses approximately $(-4 \%)$ of its value.

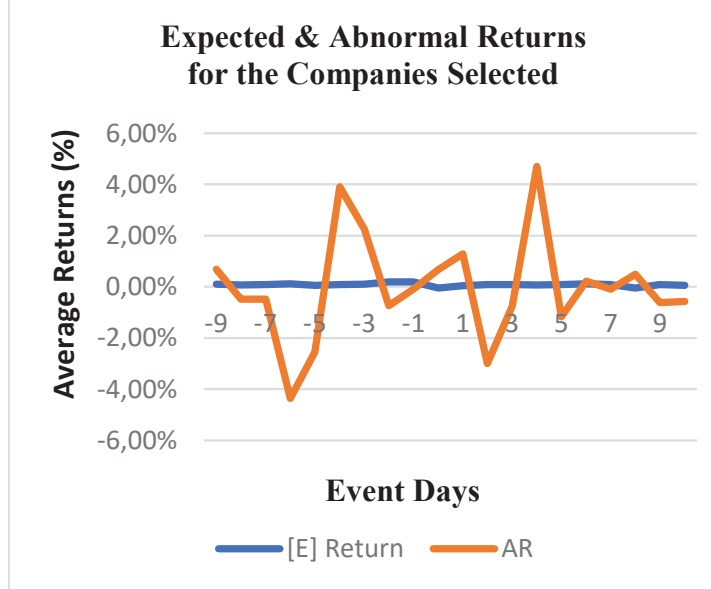

Figure 2Expected \& Abnormal Returns

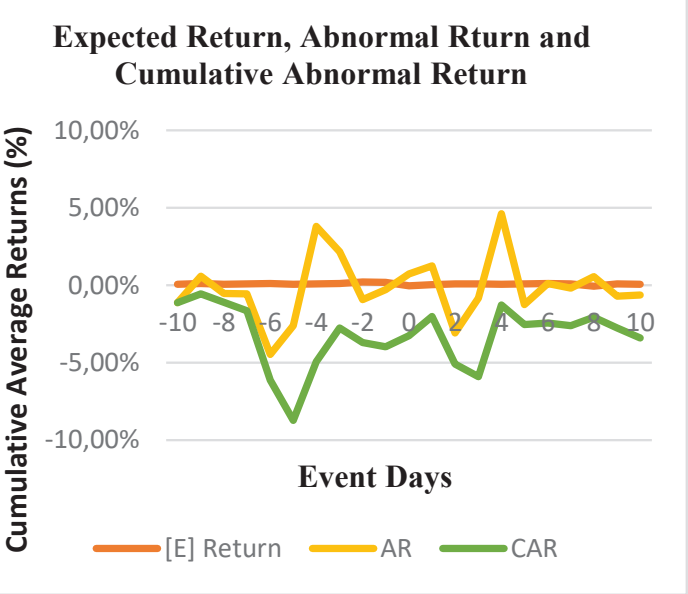

Figure 3 Exp. Return, AR, \& CAAR

Then the next day, unforeseen returns (AR) began to rise sharply until they achieved 4 percent. Therefore, the market tried to adjust its position until it witnessed a rapid decline on the day of the event to record losses of about 2 percent on the day 2. In the following day, the market became energetic to record almost 5percent profit of abnormal returns, and then suddenly collapsed to bring losses of around 3 percent. However, on the day after the event, the market managed to adjust itself, bringing in unusual returns (AR) very close to the expected returns, but it did not last long and started swinging around zero.

For further clarification, Figure 3 shows the relationship between the expected stock returns of the study companies. The abnormal returns (AR), and the accumulated abnormal returns (CAR). ARs individually presented positive and negative fluctuations intersecting with theexpected returns over the event window period. While, the CARsseem to be far from the expected returns since "he first day of the window period (10-day) before the incident. It continued along this line and did not intersect with the expected returns on any given day. 
This pattern may point to the fact that the efficiency of the Saudi stock market was weak, especially in dealing with the unexpected political event, and therefore the market could not absorb the news received, or the news was getting distorted and dealers in the market could not get the same information at the same time and time. Hence, their presence in the market has mentioned by the efficient market hypothesis $(\mathrm{EMH})$ as a requirement for stock market efficiency (Malkiel, 2003).

\section{CONCLUSION}

Obviously, the most important point to be seen by the investor is political stability. Because political stability leads to the continuity of political provisions, and the investors trust their investments and they will be able to make the right decisions at the right time and fruitful investments. Of course, the stock market is an economic indicator for any country. Money flows from the surplus to the deficit through financial intermediaries. Thus, the stock market connects different parties with common interests in a single exchange platform for financial transactions. Therefore, this study aimed to determine the relationship between the stock market returns and political instability, then how the Saudi stock market reacted towards unexpected political news (Khashoggi's disappearance) by using event study methodology. This methodology has enabled the researcher to study the impact of unanticipated political events on the "Saudi stock market", and hence, the Saudi economy.

For this purpose, ten financial companies traded in the Saudi stock market (Tadawul) from different sectors were selected. These companies constitute about 62 percent of the market capitalization of all companies listed onTadawul (See table1). The study period was defined by 250 trading days (19/12/2017 to 20/12/2018), including the assessment period and the event window. The political event was identified in the case of the disappearance of Saudi journalist Jamal Khashoggi on 02/10/2018. The study event day was set on 14 October 2018, the day after US President Donald Trump's speech denouncing the case, and Trump promised to punish Saudi Arabia if it proved the involvement of prominent officers and responsible.

The study concluded that this event affected the performance of Tadawul. The market reacted to the event and showed great interaction with it. However, the market was unable to absorb the information received and deal with it through high efficiency, and the market could not adjust itself and recover back to its previous levels. The results also showed that there were abnormal returns(ARs)through the event window period, but the directions were not one-way. A light appears positive, and another pattern appears negative within one or two days. This explains why there are risk taker-investors and others who are risk-averse. Thus, there is a difference in the expectations of each group and then the decisions made, of course, should be varied. More importantly, the levels of information that the market may have received on a daily basis are different, and thus the market loses its efficiency that it is supposed to have. Indeed, these results supported by study of Kalyanaraman, (2014)asset allocation, risk management, etc. We estimate the conditional volatility of Saudi stock market by applying AR (1. Furthermore, this sudden and rapid fluctuation has not allowed us to correctly determine the direction of the split, and therefore it is difficult to determine the relationship between the unanticipated political event and stocks' returns exactly. 


\section{Study Limitations}

Indeed, there are some limitations of this study which should be noted, namely:

o The study did not cover all the companies in the Saudi market. The sample was limited to 10 huge companies in terms of market capitalization only.

o The results of this study are limited to the period applied in this study and the sample itself if anyone changes, the results may be differed.

o The study applied event study methodology and used Excel sheet and equations were used in the calculation and assessment of the data. So, If the analysis tool or the methodology changed, the results may also vary.

\section{REFERENCES}

Baillie, R. T., \& DeGennaro, R. P. (1990). Stock Returns and Volatility. The Journal of Financial and Quantitative Analysis, 25(2), 203. https://doi.org/10.2307/2330824

Ball, R. (2014). Fama, Fisher, Jensen and Roll (1969): Retrospective Comments. In SSRN. https://doi.org/10.2139/ssrn.2396585

Brailsford, T. J., \& Robert, W. F. (1966). An Evaluation of Volatility Forecasting Techniques. Journal of Banking \& Finance, 20.3. Retrieved from https://www.sciencedirect.com/ science/article/pii/0378426695000151

Chau, F., Deesomsak, R., \& Wang, J. (2014). Political uncertainty and stock market volatility in the Middle East and North African (MENA) countries. Journal of International Financial Markets, Institutions and Money, 28(1), 1-19. https://doi.org/10.1016/j. intfin.2013.10.008

Clark, I. (1997). Globalization and fragmentation: international relations in the twentieth century. Oxford University Press, 71(4), 733-746. Retrieved from http://weekpdftom. com/globalization-and-fragmentation-international-relations-in-the-twentieth-centuryian-clark-read-without-limits-enjoy.pdf

Delcey, T., Delcey, T., Market, E., Fama, E., A, P. S., \& Delcey, T. (2018). Efficient Market Hypothesis, Eugene Fama and Paul Samuelson: A reevaluation To cite this version: HAL Id : hal-01618347 Efficient Market Hypothesis, Eugene Fama and Paul Samuelson : A reevaluation.

Dolley, J. C. (1933). Characteristics and procedure of common stock split-ups. Harvard Business Review, 11(3), 316-326.

ENGLE, R. F., \& NG, V. K. (1993). Measuring and Testing the Impact of News on Volatility. The Journal of Finance, 48(5), 1749-1778. https://doi.org/10.1111/j.1540-6261.1993. tb05127.x

Fama, E. F. (1970). Efficient Capital Markets: A Review of Theory and Empirical Work. The Journal of Finance, 25(2), 383. https://doi.org/10.2307/2325486 
Fama, E. F., Fisher, L., Jensen, M. C., Eugene Fama, B. F., \& Roll, R. (1969). The Adjustment of Stock Prices to New Information. Roll Source: International Economic Review, 10(1), 1-21. https://doi.org/10.2307/2525569

Gul, S., Khan, M. T., Saif, N., Rehman, S. U., \& Roohullah. (2013). Stock Market Reaction to Political Events ( Evidence from pakistan). Journal of Economics and Sustainable Development, 4(1), 165-175.

Gulfbase. (2018). Saudi Stock Exchange | Companies List. Retrieved January 1, 2019, from 2018 website: https://www.gulfbase.com/company-list-saudi-stock-exchange-1

Henisz,W.J.,\&Zelner,B.A.(2003).TheStrategicOrganizationofPoliticalRisksandOpportunities. Strategic Organization, 1(4), 451-460. https://doi.org/10.1177/14761270030014005

Hirschey, J.-C., \& Mark, B. (1989). The Valuation Effects of Corporate Name Changes. Financial Management, 18(4), 64-73. Retrieved from https://www.jstor.org/stable/3665798

Hovav, A., \& D'Arcy, J. (2003). The Impact of Denial-of-Service Attack Announcements on the Market Value of Firms. Risk Management <html_ent Glyph="@amp;" Ascii="\&amp;"/> Insurance Review, 6(2), 97-121. https://doi.org/10.1046/J.10981616.2003.026.x

Kalu O. Emenike. (2010). Modelling Stock Returns Volatility In Nigeria Using GARCH Models. Munich Personal RePEc Archive, (75599). Retrieved from https://mpra.ub.unimuenchen.de/22723/

Kalyanaraman, L. (2014). Stock market volatility in Saudi Arabia: An application of univariate GARCH model. Asian Social Science, 10(10), 142-152. https://doi.org/10.5539/ass. v10n10p142

MacKinlay, C., \& MacKinlay, A. C. (1997). Event studies in economics and finance. Journal of Economic Literature, XXXV(March), 13-39. https://doi.org/10.2307/2729691

Malkiel, B. G. (2003). The Efficient Market Hypothesis and Its Critics. Journal of Economic Perspectives, 17(1), 59-82. https://doi.org/10.1257/089533003321164958

Nugroho, T., Rusydiana, A. S., \& Tubastuvi, N. (2018). Micro and Small Enterprises Financing Model Through the Revolving Fund Management Institution in Indonesia: AHP Approach. IJIBE (International Journal of Islamic Business Ethics), 3(2), 496-504.

Park, N. K. (2004). A guide to using event study methods in multi-country settings. Strategic Management Journal, 25(7), 655-668. https://doi.org/10.1002/smj.399

Suleman, M. T. (2012). Stock Market Reaction to Good and Bad Political News. 4(1), 299-312. https://doi.org/10.5296/ajfa.v4i1.1705

TASI. (2018). Statistical Report Frist Nine Months 2018. Retrieved from https:// www.tadawul.com.sa/wps/wcm/connect/7d1ddb39-bdc3-4518-bef3$6 \mathrm{a} 232 \mathrm{fc} 8 \mathrm{da} 25 / \mathrm{Saudi}+$ Stock+Exchange+-Tadawul-\%2CStatistical+Report+++ Frist $+\mathrm{Nine}+\mathrm{M}$ onth s+2018.pdf? M OD=A JPERES \& CON VERT $\mathrm{TO}=$ url\&CACHEID=ROOTWORKSPACE-7d1ddb39-bdc3-4518-bef3-6a232fc8da25 
Tse, Y. K. (1991). Stock returns volatility in the Tokyo stock exchange. Japan and The World Economy, 3(3), 285-298. https://doi.org/10.1016/0922-1425(91)90011-Z

Warner, J., \& Brown, S. (1985). Using daily stock returns: The case of event studies. Journal of Financial Economics, 14, 3-31. https://doi.org/10.1016/0304-405X(85)90042-X 
APPENDIX

\begin{tabular}{|c|c|c|c|c|c|c|c|c|c|c|c|}
\hline \multicolumn{4}{|c|}{ MAADEN } & \multicolumn{4}{|c|}{ SABIC } & \multicolumn{4}{|c|}{ ALDREES } \\
\hline [E] Return & AR & CAR & Ar T-test & [E] Return & AR & CAR & Ar T-test & \begin{tabular}{|l|l|} 
[E] Return \\
\end{tabular} & AR & CAR & Ar T-test \\
\hline $0.03 \%$ & $-0.61 \%$ & $-0.61 \%$ & -0.4319 & $0.02 \%$ & $-1.62 \%$ & $-1.62 \%$ & -1.5031 & $-0.01 \%$ & $-2.63 \%$ & $-2.63 \%$ & -1.6487 \\
\hline$-0.03 \%$ & $-0.36 \%$ & $-0.36 \%$ & -0.2528 & 0.0028 & \begin{tabular}{|l|}
-0.0012 \\
\end{tabular} & $-1.74 \%$ & -1.5043 & -0.0015 & -0.0278 & $-5.41 \%$ & -1.6487 \\
\hline $0.02 \%$ & $-0.41 \%$ & $-0.41 \%$ & -0.2922 & 0.0005 & -0.0005 & $-1.79 \%$ & \begin{tabular}{|l||}
-1.5048 \\
\end{tabular} & -0.0002 & 0.0079 & $-4.62 \%$ & -1.6487 \\
\hline $0.00 \%$ & $-0.58 \%$ & $-0.58 \%$ & -0.4150 & 0.0016 & -0.0145 & $-3.25 \%$ & -1.5193 & -0.0008 & -0.0058 & $-5.20 \%$ & -1.6487 \\
\hline$-0.06 \%$ & $-7.47 \%$ & $-7.47 \%$ & -5.3073 & 0.0041 & -0.0561 & $-8.85 \%$ & -1.5754 & -0.0022 & -0.0089 & $-6.09 \%$ & -1.6487 \\
\hline $0.03 \%$ & $-7.27 \%$ & $-7.27 \%$ & -5.1632 & 0.0000 & \begin{tabular}{|l|}
-0.0191 \\
\end{tabular} & $-10.77 \%$ & -1.5945 & 0.0000 & -0.0858 & $-14.67 \%$ & -1.6487 \\
\hline$-0.02 \%$ & $3.59 \%$ & $3.59 \%$ & 2.5507 & 0.0022 & 0.0340 & $-7.37 \%$ & \begin{tabular}{|l||}
-1.5605 \\
\end{tabular} & -0.0011 & 0.0847 & $-6.20 \%$ & -1.6487 \\
\hline$-0.04 \%$ & $-1.62 \%$ & $-1.62 \%$ & -1.1493 & 0.0032 & 0.0447 & $-2.89 \%$ & -1.5158 & -0.0017 & 0.0039 & $-5.81 \%$ & -1.6487 \\
\hline$-0.20 \%$ & $1.53 \%$ & $1.53 \%$ & 1.0854 & 0.0098 & 0.0046 & $-2.44 \%$ & -1.5112 & -0.0052 & 0.0434 & $-1.47 \%$ & -1.6487 \\
\hline$-0.18 \%$ & $-0.82 \%$ & $-0.82 \%$ & -0.5801 & 0.0090 & -0.0170 & $-4.13 \%$ & -1.5282 & -0.0048 & -0.0114 & $-2.61 \%$ & -1.6487 \\
\hline $0.21 \%$ & $-2.92 \%$ & $-2.92 \%$ & -2.0719 & -0.0075 & 0.0091 & $-3.22 \%$ & \begin{tabular}{|l||}
-1.5191 \\
\end{tabular} & 0.0041 & 0.0121 & $-1.41 \%$ & -1.6487 \\
\hline $0.07 \%$ & $-6.68 \%$ & $-6.68 \%$ & -4.7450 & -0.0016 & 0.0174 & $-1.47 \%$ & \begin{tabular}{|l||}
-1.5016 \\
\end{tabular} & 0.0009 & 0.0255 & $1.14 \%$ & -1.6487 \\
\hline $0.00 \%$ & $5.92 \%$ & $5.92 \%$ & 4.2069 & 0.0015 & -0.0319 & $-4.66 \%$ & -1.5335 & -0.0008 & -0.0396 & $-2.82 \%$ & -1.6487 \\
\hline $0.00 \%$ & $6.24 \%$ & $6.24 \%$ & 4.4341 & 0.0015 & -0.0113 & $-5.80 \%$ & -1.5448 & -0.0008 & -0.0112 & $-3.94 \%$ & -1.6487 \\
\hline $0.01 \%$ & $2.12 \%$ & $2.12 \%$ & 1.5094 & 0.0009 & 0.0595 & $0.16 \%$ & -1.4853 & -0.0004 & 0.0816 & $4.22 \%$ & -1.6487 \\
\hline $0.00 \%$ & $-0.42 \%$ & $-0.42 \%$ & -0.2988 & 0.0016 & -0.0203 & $-1.87 \%$ & -1.5056 & -0.0008 & -0.0073 & $3.48 \%$ & -1.6487 \\
\hline$-0.06 \%$ & $0.91 \%$ & $0.91 \%$ & 0.6451 & 0.0041 & -0.0041 & $-2.28 \%$ & -1.5096 & -0.0021 & -0.0122 & $2.26 \%$ & -1.6487 \\
\hline$-0.02 \%$ & $0.23 \%$ & $0.23 \%$ & 0.1642 & 0.0023 & \begin{tabular}{|l|}
-0.0055 \\
\end{tabular} & $-2.83 \%$ & -1.5151 & -0.0012 & 0.0135 & $3.61 \%$ & -1.6487 \\
\hline $0.22 \%$ & $0.62 \%$ & $0.62 \%$ & 0.4379 & -0.0079 & 0.0079 & $-2.04 \%$ & -1.5073 & 0.0043 & 0.0039 & $4.00 \%$ & -1.6487 \\
\hline$-0.02 \%$ & $-2.94 \%$ & $-2.94 \%$ & -2.0913 & 0.0022 & -0.0037 & $-2.41 \%$ & -1.5110 & -0.0011 & -0.0050 & $3.50 \%$ & -1.6487 \\
\hline $0.03 \%$ & $0.18 \%$ & $0.18 \%$ & 0.1282 & 0.0000 & -0.0048 & $-2.89 \%$ & -1.5158 & 0.0000 & -0.0021 & $3.30 \%$ & -1.6487 \\
\hline \multicolumn{4}{|c|}{ SABB } & \multicolumn{4}{|c|}{ RIBL } & \multicolumn{4}{|c|}{ SAMBA } \\
\hline [E] Return & AR & CAR & Ar T-test & [E] Return & $A R$ & CAR & Ar T-test & [E] Return & AR & CAR & Ar T-test \\
\hline $0.08 \%$ & $-1.66 \%$ & $-1.66 \%$ & -0.9697 & $0.16 \%$ & $-0.16 \%$ & $-0.16 \%$ & -0.1264 & $0.17 \%$ & $-0.17 \%$ & $-0.17 \%$ & \begin{tabular}{|c|}
-0.1098 \\
\end{tabular} \\
\hline 0.0007 & 0.0166 & $0.00 \%$ & -0.9530 & 0.0010 & 0.0229 & $2.12 \%$ & 0.0229 & 0.0015 & 0.0143 & $1.26 \%$ & \begin{tabular}{|l|}
-0.0955 \\
\end{tabular} \\
\hline 0.0008 & 0.0007 & $0.07 \%$ & -0.9523 & 0.0016 & -0.0170 & $0.42 \%$ & -0.0170 & 0.0016 & -0.0158 & $-0.32 \%$ & -0.1113 \\
\hline 0.0008 & -0.0118 & $-1.10 \%$ & -0.9641 & 0.0013 & 0.0130 & $1.72 \%$ & 0.0130 & 0.0016 & 0.0048 & $0.16 \%$ & -0.1066 \\
\hline 0.0007 & -0.0542 & $-6.53 \%$ & -1.0183 & 0.0006 & -0.0441 & $-2.69 \%$ & \begin{tabular}{|l|}
-0.0441 \\
\end{tabular} & 0.0014 & -0.0565 & $-5.49 \%$ & \begin{tabular}{|l|}
-0.1631 \\
\end{tabular} \\
\hline 0.0008 & -0.0143 & $-7.95 \%$ & -1.0326 & 0.0017 & -0.0179 & $-4.47 \%$ & \begin{tabular}{|l|}
-0.0179 \\
\end{tabular} & 0.0017 & 0.0311 & $-2.38 \%$ & -0.1319 \\
\hline 0.0008 & 0.0503 & $-2.93 \%$ & -0.9823 & 0.0011 & 0.0297 & $-1.50 \%$ & 0.0297 & 0.0015 & 0.0287 & $0.49 \%$ & -0.1033 \\
\hline 0.0007 & 0.0340 & $0.47 \%$ & -0.9483 & 0.0009 & 0.0384 & $2.34 \%$ & \begin{tabular}{|l|}
0.0384 \\
\end{tabular} & 0.0014 & 0.0079 & $1.28 \%$ & \begin{tabular}{|l|}
-0.0954 \\
\end{tabular} \\
\hline 0.0005 & -0.0083 & $-0.36 \%$ & -0.9566 & -0.0009 & -0.0240 & $-0.06 \%$ & -0.0240 & 0.0009 & -0.0388 & $-2.60 \%$ & \begin{tabular}{|l|}
-0.1342 \\
\end{tabular} \\
\hline 0.0005 & 0.0287 & $2.51 \%$ & -0.9279 & -0.0006 & 0.0161 & $1.55 \%$ & 0.0161 & 0.0010 & -0.0058 & $-3.19 \%$ & \begin{tabular}{|l|}
-0.1400 \\
\end{tabular} \\
\hline 0.0011 & 0.0303 & $5.54 \%$ & -0.8976 & 0.0037 & 0.0277 & $4.32 \%$ & 0.0277 & 0.0023 & 0.0010 & $-3.09 \%$ & \begin{tabular}{|l|}
-0.1391 \\
\end{tabular} \\
\hline 0.0009 & 0.0423 & $9.77 \%$ & -0.8553 & 0.0021 & 0.0036 & $4.68 \%$ & 0.0036 & 0.0018 & 0.0607 & $2.98 \%$ & -0.0783 \\
\hline 0.0008 & -0.0738 & $2.39 \%$ & -0.9291 & 0.0013 & -0.0478 & $-0.10 \%$ & \begin{tabular}{|l|}
-0.0478 \\
\end{tabular} & 0.0016 & -0.0706 & $-4.07 \%$ & \begin{tabular}{|l|}
-0.1489 \\
\end{tabular} \\
\hline 0.0008 & -0.0145 & $0.94 \%$ & -0.9436 & 0.0013 & -0.0061 & $-0.71 \%$ & -0.0061 & 0.0016 & -0.0279 & $-6.86 \%$ & \begin{tabular}{|l|}
-0.1768 \\
\end{tabular} \\
\hline 0.0008 & 0.0442 & $5.36 \%$ & -0.8994 & 0.0015 & 0.0430 & $3.59 \%$ & 0.0430 & 0.0016 & 0.0519 & $-1.67 \%$ & -0.1248 \\
\hline 0.0008 & -0.0141 & $3.96 \%$ & -0.9135 & 0.0013 & -0.0280 & $0.79 \%$ & -0.0280 & 0.0016 & -0.0095 & $-2.62 \%$ & \begin{tabular}{|l|}
-0.1343 \\
\end{tabular} \\
\hline 0.0007 & 0.0111 & $5.07 \%$ & -0.9023 & 0.0006 & 0.0087 & $1.66 \%$ & 0.0087 & 0.0014 & -0.0126 & $-3.87 \%$ & \begin{tabular}{|l|}
-0.1469 \\
\end{tabular} \\
\hline 0.0008 & -0.0156 & $3.51 \%$ & -0.9179 & 0.0011 & 0.0001 & $1.67 \%$ & 0.0001 & 0.0015 & -0.0031 & $-4.19 \%$ & -0.1500 \\
\hline 0.0011 & -0.0041 & $3.10 \%$ & -0.9220 & 0.0037 & 0.0044 & $2.11 \%$ & \begin{tabular}{|l|}
0.0044 \\
\end{tabular} & 0.0023 & -0.0007 & $-4.25 \%$ & -0.1507 \\
\hline 0.0008 & -0.0113 & $1.97 \%$ & -0.9333 & 0.0011 & -0.0034 & $1.76 \%$ & -0.0034 & 0.0015 & -0.0064 & $-4.89 \%$ & \begin{tabular}{|l|}
-0.1571 \\
\end{tabular} \\
\hline 0.0008 & -0.0115 & $0.83 \%$ & -0.9448 & 0.0017 & -0.0157 & $0.20 \%$ & \begin{tabular}{|l|}
-0.0157 \\
\end{tabular} & 0.0017 & -0.0065 & $-5.54 \%$ & -0.1636 \\
\hline
\end{tabular}

Tables bellow show shares' returns of individual companies. 


\begin{tabular}{|c|c|c|c|c|c|c|c|c|c|c|c|}
\hline \multicolumn{4}{|c|}{ RJHI } & \multicolumn{4}{|c|}{ NCB } & \multicolumn{4}{|c|}{ STC } \\
\hline [E] Return & AR & CAR & Ar T-test & \begin{tabular}{|l|} 
[E] Return \\
\end{tabular} & AR & \begin{tabular}{l|l} 
CAR & A \\
\end{tabular} & \begin{tabular}{|l|l} 
Ar T-test & {$[E]$}
\end{tabular} & E] Return & AR & CAR & \begin{tabular}{|l|} 
Ar T-test \\
\end{tabular} \\
\hline $0.06 \%$ & $-0.52 \%$ & $-0.52 \%$ & -0.4548 & $0.12 \%$ & $-1.22 \%$ & $-1.22 \%$ & \begin{tabular}{|l|l|}
-0.8648 \\
\end{tabular} & $0.02 \%$ & $-2.06 \%$ & $-2.06 \%$ & \begin{tabular}{|l|}
1.6929 \\
\end{tabular} \\
\hline 0.0035 & 0.0124 & $0.72 \%$ & -0.4425 & 0.0018 & 0.0059 & $-0.63 \%$ & -0.8589 & 0.0026 & 0.0131 & $-0.76 \%$ & \begin{tabular}{|l|}
-1.6798 \\
\end{tabular} \\
\hline 0.0010 & -0.0055 & $0.17 \%$ & -0.4480 & 0.0013 & -0.0057 & $-1.19 \%$ & -0.8646 & 0.0005 & -0.0065 & $-1.40 \%$ & \begin{tabular}{|l|}
1.6863 \\
\end{tabular} \\
\hline 0.0021 & -0.0215 & $-1.98 \%$ & -0.4695 & 0.0015 & -0.0059 & $-1.79 \%$ & -0.8705 & 0.0014 & -0.0111 & $-2.51 \%$ & \begin{tabular}{|l|}
-1.6974 \\
\end{tabular} \\
\hline 0.0050 & -0.0498 & $-6.97 \%$ & -0.5193 & 0.0021 & -0.0588 & $-7.67 \%$ & -0.9293 & 0.0038 & -0.0221 & $-4.72 \%$ & \begin{tabular}{|l|}
-1.7195 \\
\end{tabular} \\
\hline 0.0004 & 0.0068 & $-6.28 \%$ & -0.5125 & 0.0011 & 0.0023 & $-7.43 \%$ & -0.9270 & 0.0000 & -0.0637 & $-11.10 \%$ & \begin{tabular}{|l|}
-1.7833 \\
\end{tabular} \\
\hline 0.0029 & 0.0138 & $-4.91 \%$ & -0.4987 & 0.0017 & 0.0438 & $-3.06 \%$ & -0.8832 & 0.0020 & 0.0417 & $-6.92 \%$ & \begin{tabular}{|l|}
-1.7415 \\
\end{tabular} \\
\hline 0.0040 & 0.0147 & $-3.44 \%$ & -0.4840 & 0.0019 & 0.0222 & $-0.83 \%$ & -0.8610 & 0.0029 & 0.0486 & $-2.06 \%$ & \begin{tabular}{|l|}
-1.6929 \\
\end{tabular} \\
\hline 0.0114 & -0.0126 & $-4.70 \%$ & -0.4966 & 0.0035 & -0.0388 & $-4.72 \%$ & -0.8998 & 0.0090 & -0.0345 & $-5.51 \%$ & \begin{tabular}{|l|}
-1.7274 \\
\end{tabular} \\
\hline 0.0105 & -0.0151 & $-6.21 \%$ & -0.5118 & 0.0033 & -0.0330 & \begin{tabular}{l|l|}
$-8.01 \%$ & - \\
\end{tabular} & -0.9328 & 0.0083 & 0.0100 & $-4.51 \%$ & \begin{tabular}{|l|}
-1.7174 \\
\end{tabular} \\
\hline-0.0081 & 0.0311 & $-3.10 \%$ & \begin{tabular}{|l|}
-0.4807 \\
\end{tabular} & -0.0007 & 0.0145 & \begin{tabular}{l|l}
$-6.57 \%$ & -
\end{tabular} & -0.9183 & -0.0069 & 0.0213 & $-2.39 \%$ & \begin{tabular}{|l|}
-1.6962 \\
\end{tabular} \\
\hline-0.0014 & 0.0127 & $-1.83 \%$ & -0.4680 & 0.0008 & 0.0439 & \begin{tabular}{l|l}
$-2.18 \%$ & - \\
\end{tabular} & -0.8744 & -0.0014 & 0.0226 & $-0.13 \%$ & \begin{tabular}{|l|}
-1.6736 \\
\end{tabular} \\
\hline 0.0021 & -0.0375 & $-5.59 \%$ & \begin{tabular}{|l|}
-0.5055 \\
\end{tabular} & 0.0015 & -0.0416 & $\begin{array}{l}-6.34 \% \\
\end{array}$ & -0.9160 & 0.0014 & -0.0357 & $-3.70 \%$ & \begin{tabular}{|l|}
-1.7093 \\
\end{tabular} \\
\hline 0.0021 & -0.0257 & $-8.15 \%$ & -0.5312 & 0.0015 & -0.0222 & \begin{tabular}{l|l}
$-8.56 \%$ & - \\
\end{tabular} & -0.9382 & 0.0014 & -0.0233 & $-6.03 \%$ & \begin{tabular}{|l|}
-1.7326 \\
\end{tabular} \\
\hline 0.0014 & 0.0621 & $-1.94 \%$ & -0.4691 & 0.0014 & 0.0395 & \begin{tabular}{l|l}
$-4.60 \%$ & -
\end{tabular} & -0.8986 & 0.0009 & 0.0577 & $-0.27 \%$ & \begin{tabular}{|l|}
-1.6750 \\
\end{tabular} \\
\hline 0.0022 & -0.0236 & $-4.31 \%$ & -0.4927 & 0.0015 & -0.0139 & \begin{tabular}{l|l}
$-5.99 \%$ & - \\
\end{tabular} & -0.9125 & 0.0015 & -0.0096 & $-1.23 \%$ & \begin{tabular}{|l|}
-1.6846 \\
\end{tabular} \\
\hline 0.0050 & -0.0050 & $-4.80 \%$ & -0.4977 & 0.0021 & -0.0021 & \begin{tabular}{l|l}
$-6.20 \%$ & - \\
\end{tabular} & \begin{tabular}{|l|}
-0.9146 \\
\end{tabular} & 0.0038 & 0.0021 & $-1.02 \%$ & \begin{tabular}{|l|}
-1.6825 \\
\end{tabular} \\
\hline 0.0030 & -0.0076 & $-5.56 \%$ & -0.5053 & 0.0017 & 0.0073 & \begin{tabular}{l|l}
$-5.47 \%$ & - \\
\end{tabular} & -0.9074 & 0.0022 & -0.0138 & $-2.41 \%$ & \begin{tabular}{|l|}
-1.6964 \\
\end{tabular} \\
\hline-0.0085 & 0.0131 & $-4.26 \%$ & -0.4922 & -0.0007 & 0.0152 & \begin{tabular}{|c|c}
$-3.95 \%$ & -
\end{tabular} & -0.8922 & -0.0072 & 0.0119 & $-1.22 \%$ & \begin{tabular}{|l|}
-1.6845 \\
\end{tabular} \\
\hline 0.0028 & -0.0028 & $-4.54 \%$ & -0.4951 & 0.0017 & -0.0039 & $-4.34 \%$ & -0.8961 & 0.0020 & -0.0055 & $-1.77 \%$ & \begin{tabular}{|l|}
-1.6900 \\
\end{tabular} \\
\hline 0.0004 & -0.0073 & $-5.27 \%$ & \begin{tabular}{|l|}
-0.5023 \\
\end{tabular} & 0.0011 & -0.0045 & $-4.79 \%$ & -0.9005 & 0.0000 & -0.0095 & $-2.72 \%$ & \begin{tabular}{|l|}
-1.6995 \\
\end{tabular} \\
\hline & & & & & SEC & Co & & & & & \\
\hline & & & & [E] Return & $A R$ & CAR & Ar T-test & & & & \\
\hline & & & & $-0.04 \%$ & $-0.70 \%$ & $-0.70 \%$ & \begin{tabular}{|l|l|}
5 & -0.5552 \\
\end{tabular} & & & & \\
\hline & & & & -0.0022 & 0.0060 & $-0.11 \%$ & -0.5492 & & & & \\
\hline & & & & -0.0006 & -0.0081 & $-0.91 \%$ & \begin{tabular}{|l|l|}
5 & -0.5573 \\
\end{tabular} & & & & \\
\hline & & & & -0.0014 & 0.0026 & $-0.65 \%$ & \begin{tabular}{|l|l|}
5 & -0.5547 \\
\end{tabular} & & & & \\
\hline & & & & -0.0032 & -0.0221 & $-2.86 \%$ & \begin{tabular}{|l|l|}
5 & -0.5768 \\
\end{tabular} & & & & \\
\hline & & & & -0.0003 & -0.0283 & \begin{tabular}{l|l|} 
& $-5.69 \%$ \\
\end{tabular} & \begin{tabular}{|l|l|}
5 & -0.6051 \\
\end{tabular} & & & & \\
\hline & & & & -0.0018 & 0.0188 & $-3.81 \%$ & \begin{tabular}{|l|l|}
5 & -0.5863 \\
\end{tabular} & & & & \\
\hline & & & & -0.0025 & 0.0179 & $-2.02 \%$ & \begin{tabular}{|l|l|}
5 & -0.5684 \\
\end{tabular} & & & & \\
\hline & & & & -0.0072 & 0.0008 & $-1.93 \%$ & \begin{tabular}{|l|l|}
5 & -0.5675 \\
\end{tabular} & & & & \\
\hline & & & & -0.0066 & 0.0079 & $-1.14 \%$ & \begin{tabular}{l|l|} 
& -0.5596 \\
\end{tabular} & & & & \\
\hline & & & & 0.0051 & -0.0456 & \begin{tabular}{l|l|} 
& $-5.70 \%$ \\
\end{tabular} & \begin{tabular}{|l|l|}
5 & -0.6052 \\
\end{tabular} & & & & \\
\hline & & & & 0.0009 & -0.0375 & $-9.45 \%$ & \begin{tabular}{|l|l|}
5 & -0.6427 \\
\end{tabular} & & & & \\
\hline & & & & -0.0013 & 0.0110 & $-8.36 \%$ & \begin{tabular}{|l|l|}
5 & -0.6317 \\
\end{tabular} & & & & \\
\hline & & & & -0.0013 & -0.0028 & $-8.63 \%$ & \begin{tabular}{|l|l|} 
& -0.6345 \\
\end{tabular} & & & & \\
\hline & & & & -0.0009 & 0.0023 & $-8.41 \%$ & \begin{tabular}{|l|l|}
5 & -0.6322 \\
\end{tabular} & & & & \\
\hline & & & & -0.0014 & 0.0055 & $-7.86 \%$ & \begin{tabular}{|l|l|}
5 & -0.6267 \\
\end{tabular} & & & & \\
\hline & & & & -0.0031 & 0.0154 & $-6.32 \%$ & \begin{tabular}{|l|l|}
5 & -0.6114 \\
\end{tabular} & & & & \\
\hline & & & & -0.0019 & 0.0046 & $-5.86 \%$ & \begin{tabular}{|l|l|}
5 & -0.6067 \\
\end{tabular} & & & & \\
\hline & & & & 0.0053 & -0.0026 & $-6.12 \%$ & \begin{tabular}{l|l|} 
& -0.6094 \\
\end{tabular} & & & & \\
\hline & & & & -0.0018 & 0.0005 & $-6.07 \%$ & \begin{tabular}{|l|l|}
5 & -0.6089 \\
\end{tabular} & & & & \\
\hline & & & & -0.0003 & -0.0024 & $-6.32 \%$ & \begin{tabular}{|l|l|}
5 & -0.6113 \\
\end{tabular} & & & & \\
\hline
\end{tabular}

